\title{
ANALYSIS THE WETTED AREA FOR SUBSURFACE DRIP IRRIGATION IN
} DIFFERENT SOILS TEXTURE

\section{Z. K. Rasheed}

Assist Lecturer

\section{Dept. of Water Res. Engin.-Coll. of Engin.-University of Baghdad}

kamel_zena@yahoo.com

\section{ABSTRACT}

Subsurface drip irrigation is one of the most efficient systems for management of water. This study is aimed to analysis the wetted area for subsurface drip irrigation system. Several models are developed for predicting the wetted widths and the wetted depths which are very important for designing an optimal irrigation system. HYDRUS/2D is used for predicting the dimensions of wetting patterns numerically by using the two dimensional transient flow of water from a subsurface drip irrigation through sandy loam and loamy sand soils. The wetting patterns from a subsurface drip source are simulated by using the system of United States Department of Agriculture, USDA, the wetting patterns are simulated at different values of applied heads, different diameters of drip, and different values of initial volumetric soil water contents which selected as initial conditions. In this work, greater spreading occurs in loamy sand than sandy loam in vertical and horizontal directions. Moreover, the results showed that the empirical formulas which can be used for estimating the wetting dimensions of wetted width and wetted depth in terms of initial volumetric soil water contents, applied heads, diameters of the drip and times of operation, are good with an average relative error not exceed $3 \%$, so it can be used to assist the designers in irrigation field.

Keywords: HYDRUS/2D, volumetric soil water content, subsurface drip irrigation, water management.

تحليل المنطقة المبتلة باستعمال منقطة تحت السطحية في ترب مختلفة النسجة

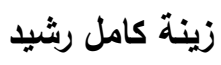$$
\text { مدرس مساعد }
$$

قسم هندسة الموارد المائية-كلية الهندسة-جامعة بفداد مداد

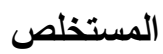

يعتبر الري بالمنقات تحت السطحية أحد أكثر أنظمة إدارة المياه كفاعة. تهاف هذه الدراسة الى تحليل المنطقة المبتلة

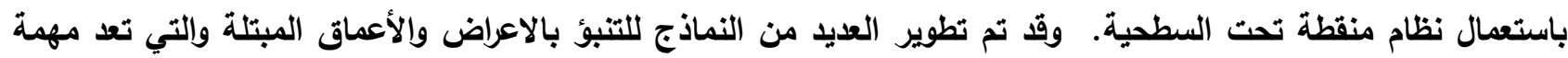

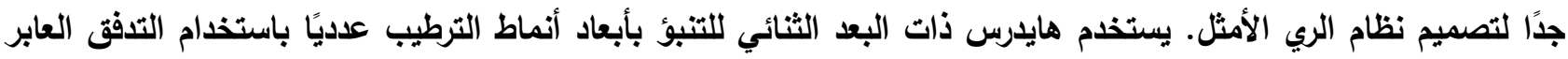

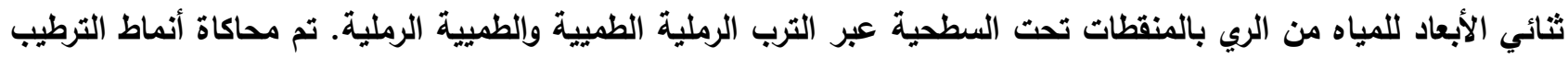

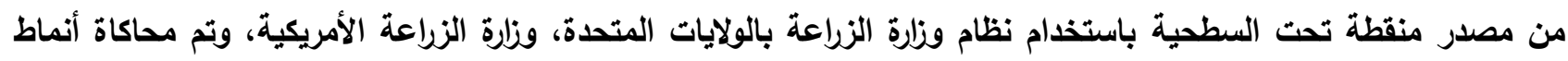
الترطيب على قيم مختلفة من الضغوط المسلطة، ويأقطار مختلفة من المنقطات، وقيم مختلفة لمحتويات الرطوية الحجمية للتربة والتي تم اختيارها كثروط أولية. في هذا العمل، يحدث انتشار أكبر في التربة الطميية الرملية أكثر من التربة الرملية الطمية وفي كلا الاتجاهين العمودي والافقي. علاوة على ذلك، أظهرت النتائج أن الصيخ التجريبية التي يمكن استخدامها لتقدير أبعاد التبلل للعرض المبلل والعمق المبلل من حيث محتويات ماء التربة الحجمية الأولية، والضغوط المسلطة، وأقطار

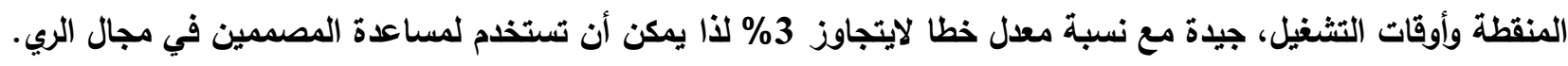
الكلمات المفتاحية: هايدرس ثناثي البعد، المحتوى الرطويي الحجمي للتربة، الري بالمنقطات تحت السطحية، ادارة المياه. 


\section{INTRODUCTION}

Subsurface drip irrigation is an efficient system by applying a specific volume of water. Moreover, water is applied slowly to the plant roots that lead to reduce the losses resulting from the conveyance, evaporation, and deep percolation. Subsurface drip irrigation is often recommended to overcome the problem of limited water resource in semi-arid and arid regions. Several additional studies are carried out with different media and assessed by many researchers, including ceramic clay pipes, plastic emitters, and pots. Assouline (3). studied the effect of conventional drip and micro drip irrigation on water distribution and uptake. He used Hydrus/2D in the numerical simulation and found that irrigation with micro drip led to the smallest wetting volume with the least gradient of water contents in vertical and horizontal axes. Ashrafi, et al. (2). analyzed the effect of soil texture for subsurface porous clay pipe irrigation. They used a program to simulate infiltration from a porous clay pipe with different applied heads that would result a different emission rate. They found that the applied head is linearly related to the emission rate. $\mathrm{Li}$, et al. (12). developed an empirical formula for predicting the wetted width and depth in terms of soil type, emitter discharge, initial soil water content and applied volume of water from a point source on two different soils namely as sandy and loamy soil. They carried out experiments with various discharges ranged between 0.6 to $7.8 \mathrm{l} / \mathrm{hr}$ for loamy soil and between 0.5 to $2 \mathrm{l} / \mathrm{hr}$ for sandy soil. They found that the wetted depth is affected to the emitter discharge and emitter spacing. Singh, et al. (16). developed a model to simulate the soil wetting patterns with a subsurface drip irrigation. They used a dimensional analysis to develop a model and they found that a model described the wetting patterns of soil well. Qiaosheng, et al. (13). simulated the soil wetting under porous clay pipe. A simple analytical model was developed by using a dimensional analysis method. They indicated from statistical analysis which used to find work accuracy that the analytical model can be used to describe the wetted soil shape. Siyal and Skaggs (17). conducted experiments on clay pipes to investigate the soil wetting patterns under this type of irrigation on various soil textures, with different heads of 25,50 , 100 and $200 \mathrm{~cm}$, operated for 5 days. They used HYDRUS/ 2D for simulation and they found that with increasing the applied heads of the system, the size of the wetted width and depth are increase. Kandelous and Simunek, (8). Simulated the movement of water by using HYDRUS/2D on subsurface drip irrigation for predicting the dimensions of wetting shape in clay loam soil. The results were compared with laboratory experiments; so they found that HYDRUS/2D can be used successfully for simulating. Han, et al. (6). studied the effect of mulch on the distribution of soil water and water content of the root zone by using the HYDRUS/2D. The simulated result was in a good agreement with the observed data obtained from the experiment. They concluded that the mulch can increase the water content of the root zone but has little effects on the distribution of soil water. Rasheed (15). developed empirical formulas in three approaches by using buried vertical ceramic pipes through different soils for the system of texture classification namely as -USDA-United States Department of Agriculture, with different conditions. These conditions include times of operation, hydraulic conductivities of the ceramic pipe, applied heads, lengths of pipes and initial volumetric soil water contents. HYDRUS/2D was used for predicting the wetted width and depth. She found a good accuracy when compared with available measured data. AlMhmdy and Al-Dulaimy (1). evaluated the performance of drip irrigation system by conducted a field experiment to obtain the best values of suggested standers. The experiment included two factors; the first factor is the emitter discharge while the second factor is the operational pressure. The results showed a decrease in both values of emission uniformity and uniformity coefficient, while the rates of discharge and variation ratios have been increased with the increase of the pressure. Khattb and El-Housini (9). carried out two field experiments to evaluate growth, yield of some lentil varieties under different irrigation systems of sprinkler and dripping in sandy soil. The results showed that drip irrigation increased all the studied characters while 
sprinkler irrigation produced the lowest values. Rahi and Faisal (14). used the system of horizontal subsurface flow constructed wetland in the treatment of municipal wastewater for agriculture purposes. The results proved a good efficiency in the treatment with removal of 84.2, 55.4 and 72.7 $\%$ while the other parameters of sulfate and total dissolved solids were less. The main aims of this work are to predict the distribution of soil water content through sandy loam and loamy sand soils, and to find an empirical formula for the wetted zone as a function of applied head, diameter of drip, initial soil water content and operating time.

\section{MATERIALS AND METHODS}

Model simulations are presented in this section which will be discussed later.

\section{Water flow equation}

The following equation is the general form of Darcy's law that can be states as [Hillel (7)]: $\mathbf{q}=-\mathbf{K}(\boldsymbol{\theta}) \boldsymbol{\nabla} \mathbf{H}$

The continuity equation for three dimensional flow is:

$\frac{\partial \theta}{\partial t}=-\nabla \cdot q$

The general form of water flow can be written as [Kirkham and Powers (10)]:

$\frac{\partial \theta}{\partial t}=\nabla \cdot[K(\theta) \nabla H]$

The total head, $\mathrm{H}$, is the sum pressure head and gravitational head. Thus the general form of Richards' equation is:

$\frac{\partial \theta}{\partial t}=\boldsymbol{\nabla} \cdot[\mathbf{K}(\mathbf{h}) \nabla \mathbf{h}+\mathbf{K}(\mathbf{h})]$

For a two dimensional porous media the flow equation will be:

$\frac{\partial \theta}{\partial t}=\frac{\partial}{\partial x}\left[K(h) \frac{\partial h}{\partial x}\right]+\frac{\partial}{\partial Z}\left[K(h) \frac{\partial h}{\partial Z}\right]+\frac{\partial K(h)}{\partial Z}$

Where:

$\theta=$ the volumetric soil water content, $L^{3} / L^{3}$,

$\mathrm{t}=$ time, $T$,

$q \quad=$ the flux density of water, $L / T$,

$\mathrm{h}=$ pressure head, $L$,

$\mathrm{K}(\theta)=$ the unsaturated soil water conductivity, $L / T$, and

$\mathrm{K}(\mathrm{h})=$ the unsaturated hydraulic conductivity of the soil as a function of pressure head, $L / T$.

HYDRUS/2D includes five analytical models for estimating the hydraulic properties which are: [Brooks and Corey (4); van Genuchten (18); Vogel and Cislerova (19); Kosugi (11); and Durner (5). Soil hydraulic properties are modeled by using the relationships of van Genuchten as follows:=

$\boldsymbol{\theta}(\mathbf{h})=\left\{\begin{array}{l}\boldsymbol{\theta}_{\mathbf{r}}+\frac{\boldsymbol{\theta}_{\mathbf{s}}-\theta_{\mathbf{r}}}{\left(1+|\alpha \mathbf{\alpha}|^{n}\right)^{\mathbf{m}}} \mathbf{h}<\mathbf{0} \\ \boldsymbol{\theta}_{\mathbf{s}} \quad \mathbf{h} \geq \mathbf{0}\end{array}\right.$

$\mathrm{K}(\mathrm{h})=\mathrm{K}_{\mathrm{s}} S_{\mathrm{e}}^{1}\left[1-\left(1-S_{\mathrm{e}}^{1 / \mathrm{m}}\right)^{\mathrm{m}}\right]^{2}$

$S_{\mathrm{e}}=\frac{\theta-\theta_{\mathrm{r}}}{\theta_{\mathrm{s}}-\theta_{\mathrm{r}}}$

$m=1-1 / n$

Where:

$\theta(h)=$ water content as a function of pressure head, $L^{3} / L^{3}$,

$\theta_{r} \quad=$ residual soil water content, $L^{3} / L^{3}$,

$\theta_{s}=$ saturated soil water content, $L^{3} / L^{3}$

$\alpha=$ the air entry inverse, $L^{-1}$,

$K_{S}=$ saturated hydraulic conductivity of the soil, $L / T$

$S_{e}=$ the effective saturation, $L^{3} / L^{3}$,

$l=$ the pore conductivity parameter, dimensionless, and

$n=$ the pore size distribution index, dimensionless

Initial and boundary conditions are required to solve equation (5). For simulations of subsurface drip, a rectangular domain is used except the left side of semicircle shape that represents the location of the dripper. The initial condition is the volumetric water content which is specified inside the domain of flow. While a variable head boundary condition is used at the dripper. Fig. 1 shows the domain section that considered for work. The domain section consists of two parts of cells; the first part is the cells which are along the soil outside the dripper. While the second part of cells is the dripper.

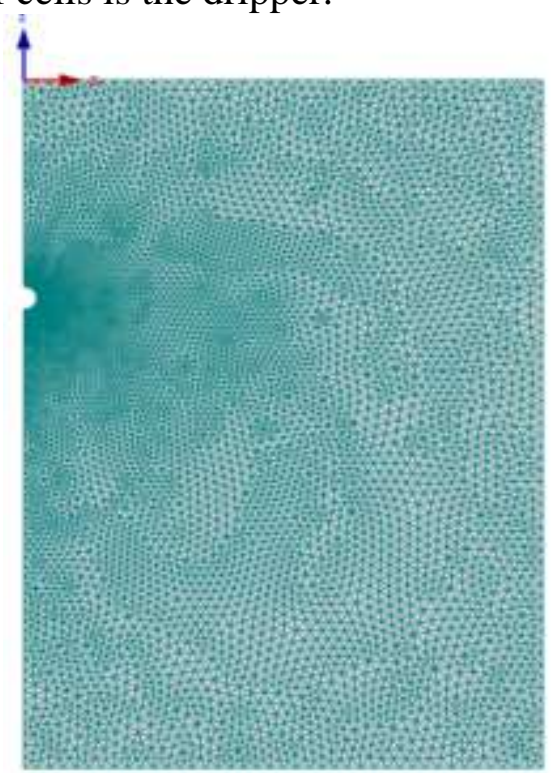

Fig. 1. The domain section 


\section{Main assumptions}

In this work, the main assumptions are, neglect the evaporation of soil surface during water application, soil is isotropic and homogeneous, and use regular distribution of initial volumetric soil water content through soil profile.

\section{Initial and boundary conditions}

The simulation is carried out only on the right of the profile due to symmetry. The initial condition is taken as the initial soil water content of the soil which is along the soil profile. The reference coordinate is at the right edge of the top while the drip is installed at $20 \mathrm{~cm}$ below the soil surface from the right. Variable head is taken along the drip as the first boundary condition, the free drainage boundary condition is at the bottom of the soil profile while the other parts of the domain is taken as no flux boundary conditions.

\section{Numerical simulations}

Subsurface drip irrigation is simulated by using the system of soil classification of United States Department of Agriculture, (USDA). The following initial volumetric soil water contents of the two soils are enclosed between residual volumetric soil water content and saturated, which differs in both soils as shown in Table 1. Two types of soils are used namely as sandy loam and loamy sand.

Table 1. Initial soil water contents of the two soils

\begin{tabular}{|lccc|}
\hline \multirow{2}{*}{ Soil texture } & \multicolumn{3}{c|}{ Values of initial soil water contents, } \\
& \multicolumn{3}{c|}{$\mathbf{c m}^{3} / \mathbf{c m}^{3}$} \\
\hline Sandy loam & 0.19 & 0.20 & 0.21 \\
Loamy sand & 0.17 & 0.18 & 0.19 \\
\hline
\end{tabular}

Three hydraulic heads were used for the two soils that were 10,15 , and $20 \mathrm{~cm}$ which applied at the soil surface. $20 \mathrm{~cm}$ is added for each head as the installed depth of the drip. As mention above, HYDRUS/2D is used for predicting the wetted patterns for the two soils under several boundary conditions. The simulations were carried out by using three diameters of drips; these diameters were $1,1.5$, and $2 \mathrm{~cm}$ installed at $20 \mathrm{~cm}$ below the soil surface. In HYDRUS/2D simulations, a rectangular domain of $40 \mathrm{~cm}$ wide and $60 \mathrm{~cm}$ depth were used.

\section{RESULTS AND DISCUSSION}

Influence of different parameters: The shapes of wetting patterns are affected by the inputs parameters including soil texture (sandy loam or loamy sand), applied heads, initial soil water contents, drip diameters, and time of operation. For the last case of maximum applied head of $20 \mathrm{~cm}$, maximum diameter of $2 \mathrm{~cm}$, after $15 \mathrm{~min}$ operating time, and with the same initial soil water content of $0.19 \mathrm{~cm}^{3} / \mathrm{cm}^{3}$, the increasing value in $\mathrm{x}$ - direction is about $60 \%$ in loamy sand than sandy loam while the increasing value in $\mathrm{z}$ - direction is about $40 \%$ also in loamy sand than sandy loam.

\section{Effect of soil texture}

Figure 2 shows the effect of soil texture by using the two soils of sandy loam and loamy sand. A large dimension in loamy sand than sandy loam that is associated with the saturated hydraulic conductivity for the two soils, and hence is strongly affected by the texture of the soil

\section{Effect of applied heads}

Figure 3 illustrates the effect of applied heads by using loamy sand soil. As the applied head increased, more water is leaks out from the drippers. However, it is obvious that large dimensions occur in loamy sand than sandy loam in both directions, with the same conditions for the other parameters.

\section{Effect of initial soil water contents}

Effect of initial soil water contents are shown in Fig. 4 by using loamy sand soil.

\section{Effect of drip diameters}

Also the shape geometry is affected to the diameter of drip as shown in Fig. 5 by using loamy sand soil with multiple diameters of 1 , 1.5 , and $2 \mathrm{~cm}$ with the same condition.

\section{Effect of operation times}

As the time increased more advanced in the wetting pattern is occurs. Figure 6 illustrates the effect of operation times by using loamy sand soil. 


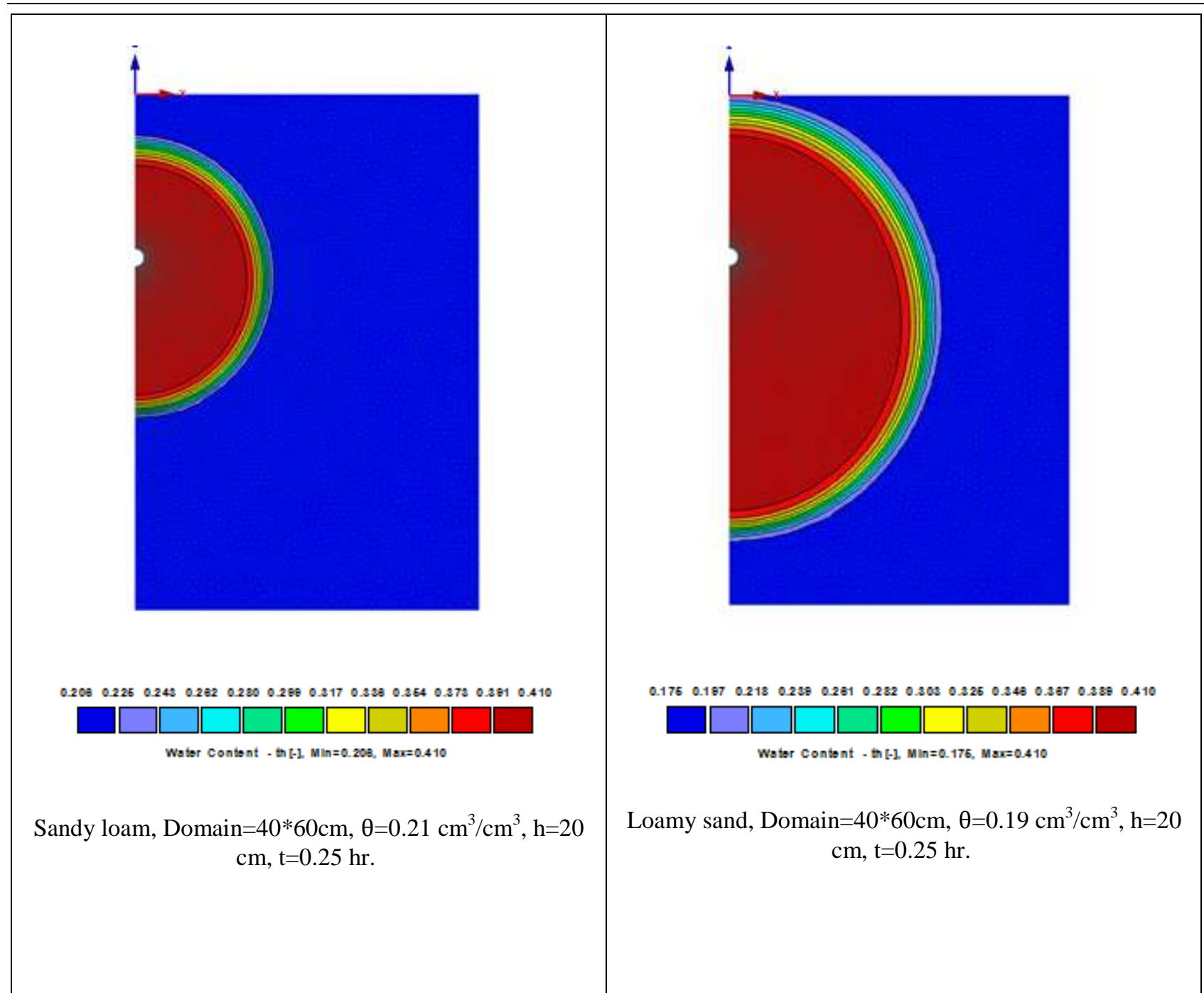

Fig. 2. Simulations of the wetting patterns for a subsurface drip irrigation in sandy loam and loamy sand soils with $2 \mathrm{~cm}$ drip diameter, and after $0.25 \mathrm{hr}$ operating time 

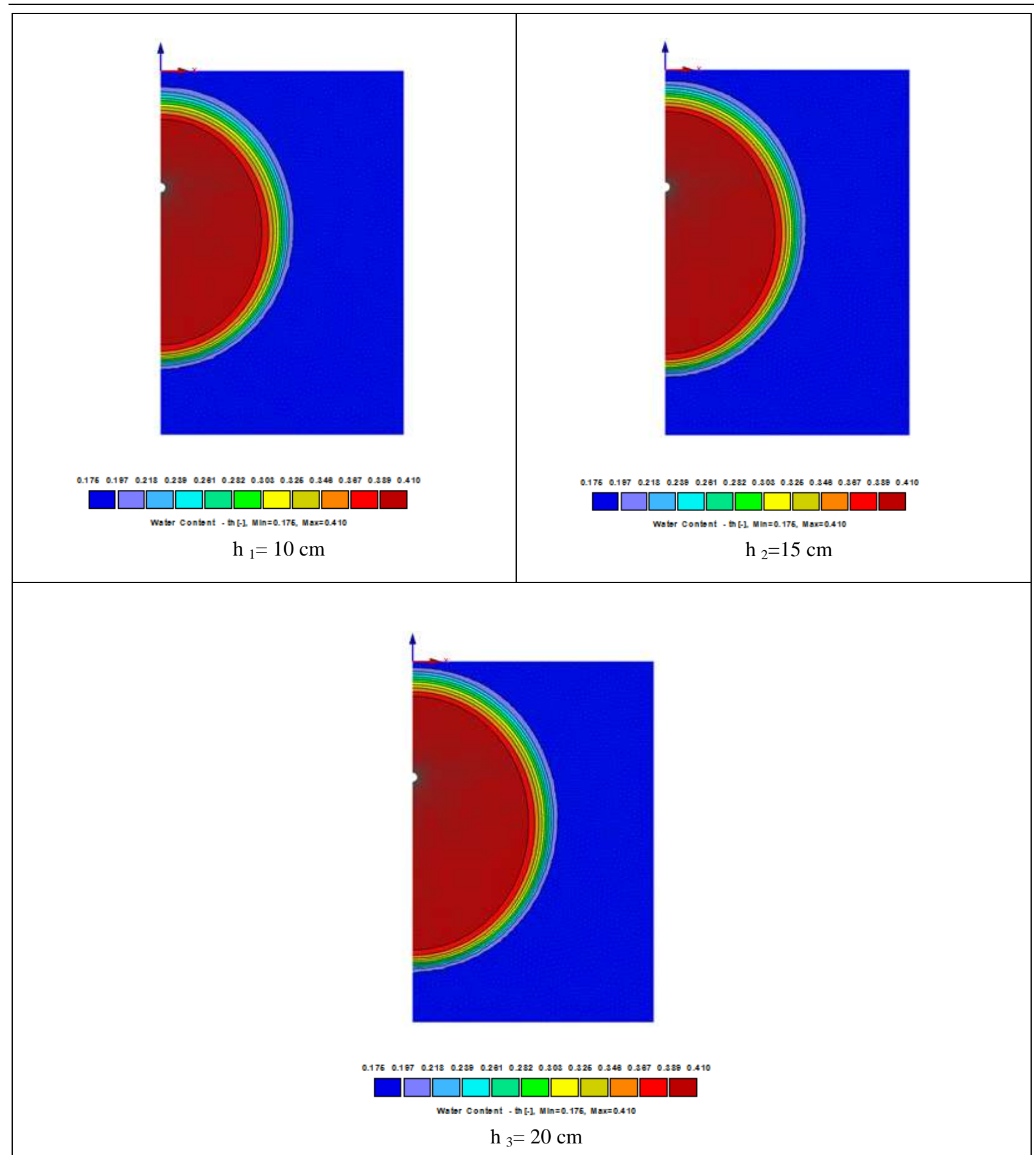

Fig. 3. Simulations of the wetting patterns for a subsurface drip irrigation in loamy sand soil with $1.5 \mathrm{~cm}$ drip diameter, with $40 \times 60 \mathrm{~cm}$ domain, initial soil water content $=0.19 \mathrm{~cm}^{3} / \mathrm{cm}^{3}$, and with different applied heads after $0.25 \mathrm{hr}$ operating time 


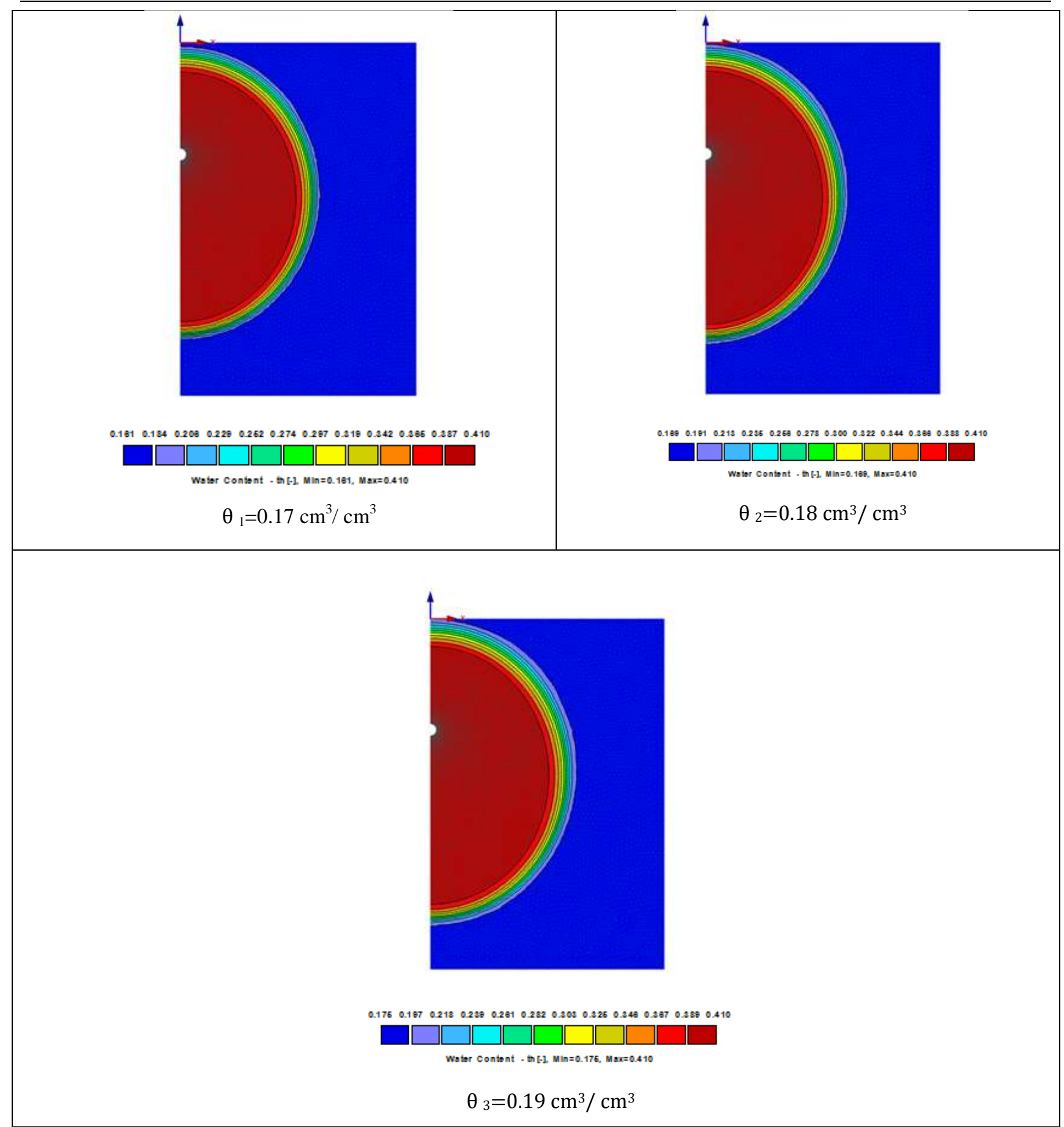

Fig. 4. Simulations of the wetting patterns for a subsurface drip irrigation in loamy sand soil with $2 \mathrm{~cm}$ drip diameter, with $40 \times 60 \mathrm{~cm}$ domain, applied head $=20 \mathrm{~cm}$, and with different initial soil water contents after $0.25 \mathrm{hr}$ operating time 


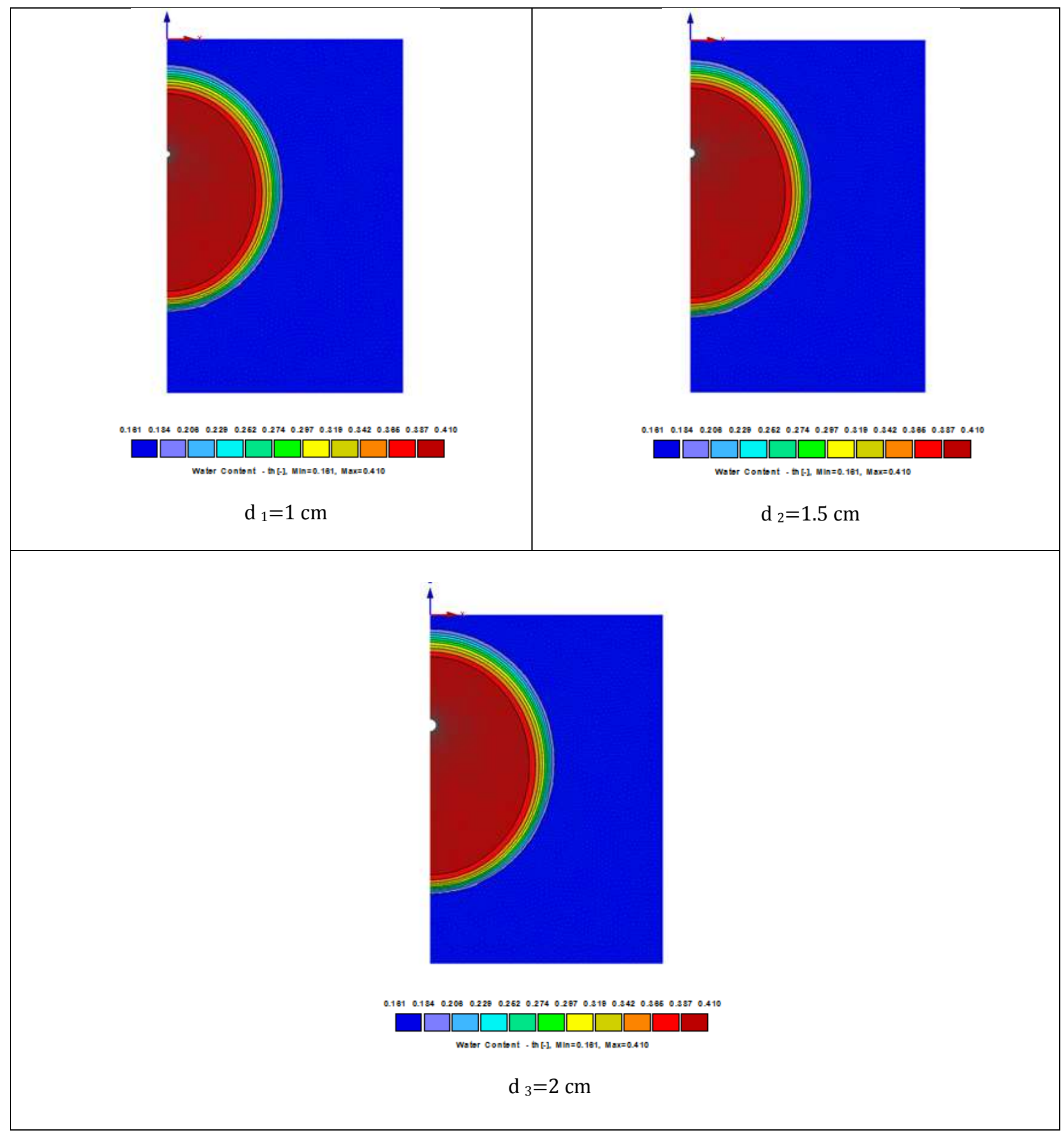

Fig. 5. Simulations of the wetting patterns for a subsurface drip irrigation in loamy sand soil with initial soil water content $=0.17 \mathrm{~cm}^{3} / \mathrm{cm}^{3}$, with $40 \times 60 \mathrm{~cm}$ domain, applied head $=10 \mathrm{~cm}$, and with different diameters of drip after $0.25 \mathrm{hr}$ operating time 


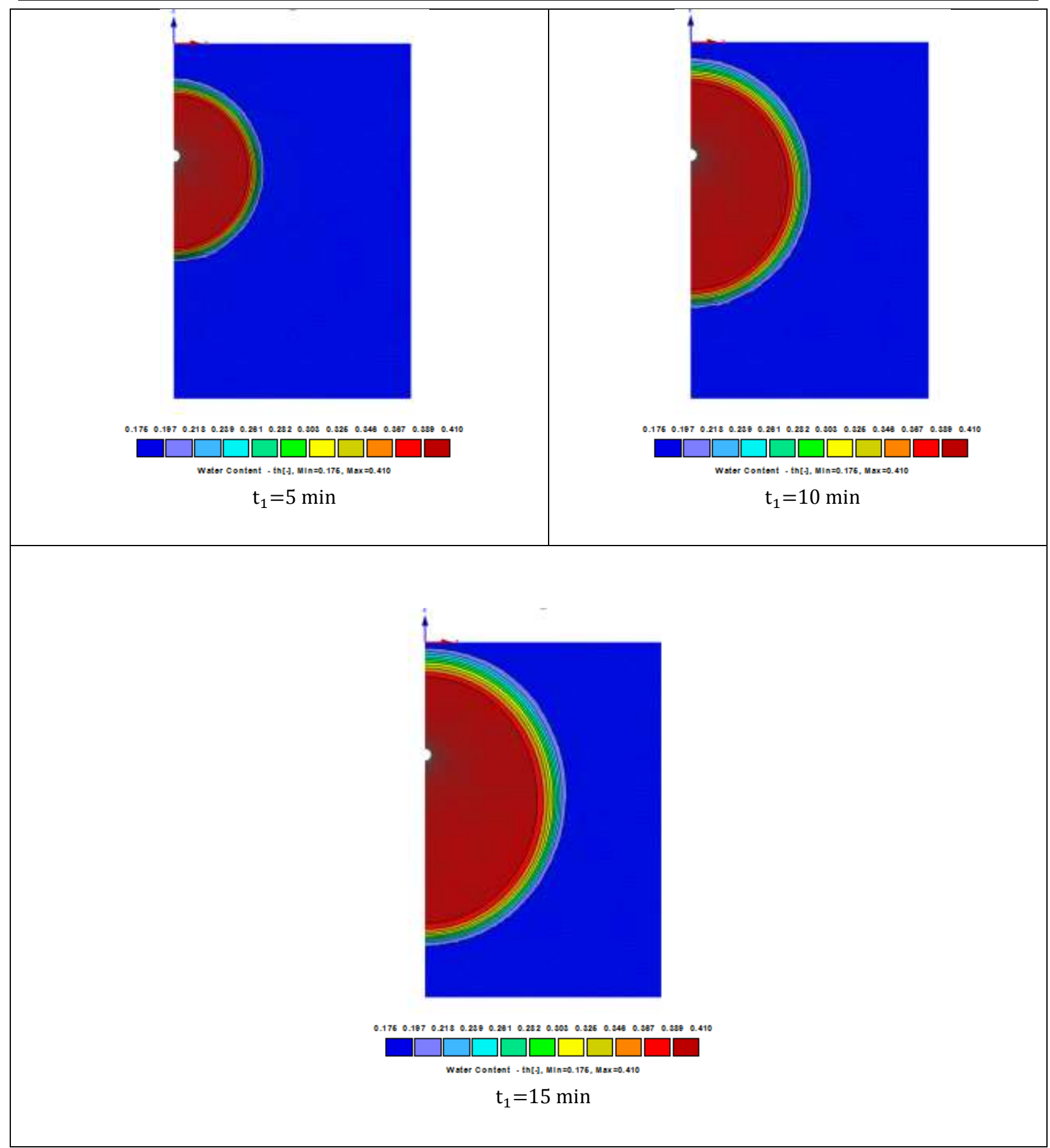

Fig. 6. Simulations of the wetting patterns for a subsurface drip irrigation in loamy sand soil with $2 \mathrm{~cm}$ drip diameter, with $40 \times 60 \mathrm{~cm}$ domain, applied head $=15 \mathrm{~cm}$, initial soil water contents $=0.19 \mathrm{~cm}^{3} / \mathrm{cm}^{3}$, and after different operation times

\section{Empirical formulas}

Version 10 of the software STATISTICA is used to develop an empirical formula for predicting the wetted width as well as the wetted depth in both soils of sandy loam and loamy sand. STATISTICA software is working with analysis of a multiple regression. Numerous data of the both soils texture are obtained from the HYDRUS/2D, which are the maximum wetting width and depth in different periods through operating time. Data which obtained from HYDRUS/2D are gathered in the software STATISTICA, these are the maximum wetting widths, the maximum wetting depths, initial volumetric soil water contents, and applied heads through different periods of the operation time as mention above. Table 2 and Table 3 show empirical formulas for predicting 
the wetted width and the wetted depth in both soils.

Table 2. Empirical formulas for predicting the wetted width in both soils.

\begin{tabular}{|cc|}
\hline Soil texture & Wetted Width, $X, \mathbf{c m}$ \\
\hline Sandy loam & $6.757 \mathbf{t}^{0.405} \mathbf{d}^{0.159} \mathbf{h}^{0.129} \theta^{0.462}$ \\
Loamy sand & $11.743 \mathrm{t}^{0.412} \mathrm{~d}^{0.136} \mathbf{h}^{0.139} \theta^{0.524}$ \\
\hline
\end{tabular}

Table 3. Empirical formulas for predicting the wetted depth in both soils

\begin{tabular}{|cc|}
\hline Soil texture & Wetted Depth, $\mathrm{Z}, \mathrm{cm}$ \\
\hline Sandy loam & $28.085 \mathbf{t}^{0.147} \mathbf{d}^{0.036} \mathbf{h}^{0.045} \boldsymbol{\theta}^{0.191}$ \\
Loamy sand & $35.200 \mathrm{t}^{0.231} \mathbf{d}^{0.046} \mathbf{h}^{0.063} \boldsymbol{\theta}^{0.291}$ \\
\hline
\end{tabular}

To evaluate the performance of formulas three statistical parameters are used for comparison of measured data (obtained from HYDRUS/2D) with calculated data (obtained from empirical formulas). These statistical parameters are coefficient of determination, maximum relative error (Max. RE), and the average relative error (AV. RE) as shown in Table 4 and Table 5. The relationships which describe the statistical parameters are [(Willmott (20)].

Table 4. Statistical parameters for wetted width in both soils.

\begin{tabular}{|lccc|}
\hline Soil texture & R2 & Max. RE \% & AV. RE \% \\
\hline Sandy loam & 0.999 & 4.672 & 0.847 \\
Loamy sand & $\mathbf{0 . 9 9 9}$ & 2.740 & 0.625 \\
\hline
\end{tabular}

Table 5. Statistical parameters for wetted depth in both soils

\begin{tabular}{|cccc|}
\hline Soil texture & R2 & Max. RE \% & AV. RE \% \\
\hline Sandy loam & $\mathbf{0 . 9 8 9}$ & 4.791 & $\mathbf{1 . 6 7 4}$ \\
Loamy sand & $\mathbf{0 . 9 8 1}$ & $\mathbf{7 . 4 0 0}$ & $\mathbf{2 . 5 9 0}$ \\
\hline
\end{tabular}

From Table 4 and Table 5, it can be seen that a good accuracy are obtained from the two soils for predicting the wetted width and the wetted depth. The percentage of maximum relative error varies from $2.74 \%$ to $7.40 \%$ while the percentage of average relative error varies from $0.625 \%$ to $2.590 \%$ in both soils texture. As it has been found from pervious study that water scarcity is becoming a major problem around the world, thus numerical and laboratory experiments are carried to improve management of water. So, the main aim of this study is to analysis the wetted area for subsurface drip irrigation in different soils texture by observe the distribution of soil water contents through two types of soils (sandy loam and loamy sand), and find appropriate empirical formulas for predicting the wetted width and the wetted depth for the two soils texture. These formulas are functions of operation times, diameters of drip, applied heads, and initial soil water contents. The main result of this research showed that the wetting patterns extend vertically much more than horizontal direction especially in loamy sand soil. As a conclusion, the increasing value in $\mathrm{x}$ - direction is about $60 \%$ in loamy sand than sandy loam soil while the increasing value in $\mathrm{z}$ - direction is about $40 \%$ also in loamy sand than sandy loam. The wetting zones increase as diameter of drip increase. Finally, on the basis of the statistical parameters, such as the coefficient of determination, maximum relative error, and the average relative error of the empirical formulas for the wetted width and the wetted depth, it can be concluded that the formulas are good enough to be used as designed equations.

\section{REFERENCES}

1. Al-Mhmdy, SH.M. and S.E.H. Al-Dulaimy. 2018. Performance evaluation of drip irrigation system according to the suggested standards. Iraqi Journal of Agriculture Sciences, 49(6): 1099-1109

2. Ashrafi, S., A.D. Gupta, M.S. Babel, N. Izumi and R. Loof. 2002. Simulation of infiltration from porous clay pipe in subsurface irrigation. Hydrological Sciences Journal, 47(2): 253-268

3. Assouline, S. 2002. The effects of microdrip and conventional drip irrigation on water distribution and uptake. Soil Sci. Soc. Am. J., 66(5): 1630-1636.

4. Brooks, R.H. and A.T. Corey. 1964. Hydraulic properties of pouros media . Hydrol. Paper, 3, Colorado State Univ., Fort Collins, CO, USA

5. Durner, W. 1994. Hydraulic conductivity estimation for soils with hterogeneous pore structure. Water Resour. Res., 30(2): 211-223

6. Han, M., C. Zhao, G. Feng, Y. Yan and Y. Sheng. 2015. Evaluating the effects of mulch and irrigation amount on soil water distribution and root zone water balance using HYDRUS-2D. Water, 7(6): 2622-2640

7. Hillel, D. 1980. Fundamentals of soil physics. Academic Press, New York

8. Kandelous, M.M. and J. Simunek. 2010. Numerical simulations of water movement in 
subsurface drip irrigation system under field and laboratory conditions using HYDRUS-2D. Agricalture Water Mangement, 97(7): 10701076

9. Khattb, E.A. and E.A. El-Housini. 2019. Evaluation of some lentil varieties under sprinkler and dripping irrigation systems in newly reclaimed sandy soil. Iraqi Journal of Agriculture Sciences, 50(3):753-758

10. Kirkham, D. and W.L. Powers. 1972. Advanced soil physics. Wiley - Interscince, New York, pp.534

11. Kosugi, K. 1996. Lognormal distribution model for unsaturated soil hydraulic properties. Water Resour. Res., 32(9): 26972703

12. Li, J., J. Zhang and B. Li. 2004. Drip irrigation design based on wetted soil geometry volume from a surface point source. Amer. Soc. Agr. Eng., ASAE Annual International Meeting, 1-4 August, the Westin, Government Center, Ottawa, Ontario, Canada 13. Qiaosheng, S., L. Zuoxin, W. Zhenying and L. Haijun. 2007. Simulation of the soil wetting shape under porous pipe sub-irrigation using dimensional analysis. Irrig. Drain. 56(4): 389-398

14. Rahi, M.A. and A.A.H Faisal. 2019. Using horizontal subsurface flow constructed wetland system in the treatment of municipal wastewater for agriculture purpuses. Iraqi
Journal of Agriculture Sciences, 50(4): 12081217

15. Rasheed, Z.K. 2017. Water Movement From Buried Vertical Ceramic Pipes Though Soils. M.Sc. Thesis, Dept. of Water Resources Engin., Coll. of Engin., Univ. of Baghdad, pp.53

16. Singh, D.K., T.B.S. Rajput, D.K. Singh, H.S. Sikarwar, R.N. Sahoo and T. Ahmad. 2006. Simulation of soil wetting pattern with subsurface drip irrigation from line source. Agricultural Water Management, 83(1): 130134

17. Siyal, A.A., and T.H. Skaggs. 2009. Measured and simulated soil wetting patterns under porous clay pipe sub-surface irrigation. Agricultural Water Management, 96(6): 893904

18. Van Genuchten, M.Th. 1980. A closedform equation for predicting the hydraulic conductivity of unsaturated soils. Soil Sci. Soc. Amer. J., 44(5): 892-898

19. Vogel, T., and M. Cislerova. 1988. On the reliabity of unsaturated hydraulic conductivity calculated from moisture retention curve. Transport in Porous Media, 3: 1-15

20. Willmott, C. J. 1982. Some commets on the evaluation of model performance. Bulletin of the American Meteorological Society, 63(11): 1309-1313. 